Jurnal Health Sains: p-ISSN: 2723-4339 e-ISSN: 2548-1398

Vol. 3, No. 1, Januari 2022

\title{
PENGARUH MONITORING OBAT, KONSELING OBAT DAN IDENTIFIKASI MrPS TERHADAP PENERAPAN KESELAMATAN PASIEN
}

\author{
Mulisda Mardiantina \\ Universitas Esa Unggul, Jakarta, Indonesia \\ Email: mulisda.mardiantina@gmail.com
}

\begin{abstract}
\begin{tabular}{ll}
\hline INFO ARTIKEL & ABSTRAK \\
\hline Diterima & Keselamatan Pasien merupakan sesuatu yang jauh lebih penting dari
\end{tabular}
5 Januari 2022 pada sekedar efisiensi pelayanan. Pengetahuan dan keterampilan tenaga

Direvisi farmasi di rumah sakait sangat berperan penting dalam pelaksanaan

15 Januari 2022 keselamatan pasien. Perilaku yang tidak paham, lupa, kurangnya

Disetujui perhatian, kecerobohan, dan tidak teliti menjaga keselamatan pasien

25 Januari 2022 akan berisiko untuk terjadinya kesalahan dan akan mengakibatkan

Kata Kunci: cedera pada keselamatan pasien. Tujuan penelitian ini menganalisis monitoring obat; pengaruh monitoring obat, konseling obat dan identifikasi MRPs konseling obat; terhadap penerapan keselamatan pasien. Metode penelitian ini adalah identifikasi mrps; cross sectional. Populasi pada penelitian ini adalah seluruh tenaga keselamatan pasien farmasi yang bekerja di rumah sakit $\mathrm{X}$ di Tangerang. Teknik pengambilan sampel menggunakan purposive sampling yang melibatkan 28 tenaga farmasi sebagai responden. Instrument yang digunakan yaitu dengan kuesioner dan lembar observasi kemampuan tenaga farmasi tentang keselamatan pasien. Hasil analisis menunjukkan nilai $\mathrm{p}$ pada monitoring obat yaitu $\mathrm{p}=0,009$, konseling obat yaitu $\mathrm{p}=0,002$ dan identifikasi MRPs yaitu $p=0,000$. Semua nilai $p$ lebih kecil dari nilai $\alpha=0,05$ sehingga dapat disimpulkan terdapat pengaruh postif dan signifikan antara monitoring obat, konseling obat dan identifikasi MRPs terhadap penerapan keselamatan pasien. Saran dari penelitian ini bagi rumah sakit lebih meningkatkan mutu pelayanan keperawatan yang berkaitan dengan keselamatan pasien sesuai dengan panduan nasional keselamatan pasien.
\end{abstract}

\section{ABSTRACT}

Patient safety is something much more important than just service efficiency. The knowledge and skills of hospital pharmacists play an important role in the implementation of patient safety. Behavior that does not understand, forget, lack of attention, carelessness, and carelessness in maintaining patient safety will risk errors and will result in injury to patient safety. The purpose of this study was to analyze the effect of drug monitoring, drug counseling and identification of MRPS on the implementation of patient safety. This research method is cross sectional. The population in this study were all pharmacists who worked at hospital $X$ in Tangerang. The sampling technique used purposive sampling which involved 28 pharmacists as respondents. The instrument used is a questionnaire and an observation sheet on the ability of pharmacists about patient safety. The results of the analysis showed that the $p$ value for drug monitoring is $p=0.049$, drug counseling is $p=$ 0.018 and the identification of MRPs is $p=0.000$. All $p$ values are smaller than $=0.05$ so it can be concluded that there is a positive and

How to cite:

E-ISSN:

Published by:
Mardiantina. M. (2022) Pengaruh Monitoring Obat, Konseling Obat dan Identifikasi MRPs terhadap Penerapan Keselamatan Pasien. Jurnal Health Sains 3(1). https://doi.org/10.46799/jhs.v3i1.397 $2723-6927$

Ridwan Institute 
Keywords:

drug monitoring;

drug counseling;

identification of

mrps; patient safety significant effect between drug monitoring, drug counseling and identification of MRPs on the implementation of patient safety. Suggestions from this study for hospitals to further improve the quality of nursing services related to patient safety in accordance with national patient safety guidelines.

\section{Pendahuluan}

Rumah sakit sebagai salah satu institusi pelayanan kesehatan memiliki fungsi penting dalam meningkatkan derajat kesehatan masyarakat sehingga dituntut untuk selalu meningkatkan mutu pelayanan yang diberikan (Depkes, 2008). Mutu pelayanan dapat dikatakan baik apabila rumah sakit dapat memberikan pelayanan yang bermutu dengan memperhatikan segala aspek (FingkyLestari \& Aisa, 2017).

Salah satu aspek yang menunjukan bahwa pelayanan di rumah sakit bermutu adalah monitoring obat, konseling, identifikasi MRPs dan keselamatan pasien. Selama proses perawatan pasien, keselamatan penting diperhatikan (Tan \& Khasiat, 2007). Hal ini akan memberikan rasa aman kepada pasien selama di rumah sakit. Oleh karena itu, rumah sakit dan tenaga kesehatan wajib melaksanakannya. Dalam menjalankan keselamatan pasien, ada sasaran yang harus dicapai. Namun, dalam proses pencapaiannya ada faktor-faktor yang mempengaruhi, antara lain tenaga apoteker, tingkat pengetahuan perawat, sikap perawat, serta fasilitas rumah sakit (Hadiyana, 2016).

Penerapan keselamatan pasien pada pasien rawat inap dapat mempercepat proses penyembuhan dan memperpendek masa rawat pasien di rumah sakit serta dapat mencegah cedera pada pasien (Basabih, 2018). Keberhasilan penerapan keselamatan pasien dapat dicapai apabila masalah yang mengancam keselamatan pasien dapat diketahui dengan cepat selama perawatan di rumah sakit (Ismainar, 2015).

Monitoring obat tidak semua dilakukan karena keterbatasan tenaga apoteker dan belum adanya apoteker farmasi klinis.
Berdasarkan hasil wawancara didapatkan juga serah terima obat antara unit farmasi dan perawat unit rawat inap tidak sesuai dengan standar prosedur operasional yang telah ditetapkan, dimana serah terima dilakukan tanpa mengisi lembar formulir pengkajian resep meliputi tujuh benar obat dan serah terima sering dilakukan secara lisan tanpa melakukan ceklis dilembar yang telah disediakan (Kazemian et al., 2017).

Selain itu, berdasarkan beberapa fakta bahwa pemberian konseling mempengaruhi hasil dari terapi, terutama pada beberpa jenis penyakit. Konseling juga merupakan salah satu dari monitoring terapi dalam pengobatan yang memberikan kesempatan bagi apoteker untuk memberikan layanan secara langsung kepada pasien (Setiawati \& Bustami, 1995). Konseling dimulia dengan fokus pada pasien, memberikan informasi yang berkaitan dengan obat, menjelaskan tanggung jawab pasien untuk mengikuti petunjuk yang sesuai untuk pasien. Pelanggan apotek menganggap masih ada perbedaan yang sanngat besar antara harapan dengan pengalaman layanan konseling yang diterima. Salah satu permasalah yang juga terjadi adalah ketika pasien mendapatkan perubahan resep obat dengan yang biasanya mereka gunakan, sehingga pasien merasa sulit dalam mengungkapkan pelayanan konseling seperti persepsi pasien yang berbeda dengan penyampaian, bahasa sehari-hari yang digunakan, dan perbedaan persepsi dikarekan usia dan lainnya, meskipun pasien mengalami beberapa masalah yang terkait dengan penjelasan pengobatan (Wongkar, 2000). Untuk mendorong minat konseling petugas apoteker harus dapat mengidentifikasi dari 
proses konseling dalam memonitoring pemberian obat kepada pasien.

Pelaporan insiden keselamatan pasien adalah suatu sistem untuk mendokumentasikan laporan insiden keselamatan pasien, analisis, dan solusi untuk pembelajaran. Pelaporan ini termasuk kejadian Medication Related Problems (MRPs) yang berisiko terhadap keselamatan pasien. Pelaporan insiden keselamatan pasien di rumah sakit cenderung rendah. Menurut hasil penelitian (Iskandar, 2018), ada beberapa faktor yang mempengaruhi rendahnya pelaporan insiden keselamatan pasien rumah sakit yaitu: (1) takut disalahkan, (2) komitmen kurang dari manajemen dan unit terkait, (3) tidak ada reward dari rumah sakit jika melaporkan, (4) tidak tahu Batasan mana atau apa yang harus dilaporkan, (5) Sosialisasi insiden keselamatan pasien kurang maksimal, (6) belum ikut pelatihan dan (7) Sosialisasi TKP-RS kurang aktif (Basabih, 2018).

Berdasarkan dari laporan bagian mutu pada tahun 2020, terjadi insiden keselamatan pasien yaitu Kejadian Potensial Cidera (KPC) terjadi 16 insiden, Kejadian Nyaris Cidera (KNC) 12 kejadian, Kejadian Tidak Cidera (KTC) 5 kejadian dan 2 Kejadian Tidak Diharapkan (KTD). Standar mutu untuk tidak terjadinya insiden adalah 0 kejadian. Insiden $\mathrm{KPC}, \mathrm{KNC}, \mathrm{KTC}$ dan KTD yang terjadi menandakan belum tercapainya mutu keselamatan pasien rumah sakit.

Dalam penelitian ini di Rumah Sakit X Tangerang merupakan rumah sakit yang terletak di Tangerang Banten. Rumah sakit ini adalah rumah sakit tipe $\mathrm{C}$ yang didirikan secara permanen untuk jangka waktu lama dalam menyelenggarakan pelayanan kesehatan perorangan secara paripurna yang menyediakan pelayanan rawat inap, rawat jalan dan gawat darurat. Saat ini sudah tersedia sejumlah 150 bed dengan jumlah pasien rawat jalan perbulan 13.710 pasien dan rawat inap 9701 pasien tiap bulannya. Terdiri dari 19 poliklinik spesialis dan 1 poliklinik umum. Instalasi farmasi terdiri dari pelayanan farmasi rawat jalan rawat inap, dan obat bebas. Di Rumah Sakit X Tangerang masih adanya insiden terkait obat yang disebabkan kurangnya ketelitian dan konsentrasi dari tenaga farmasi. Kejadian lainnya adalah tidak adanya monitoring obat oleh apoteker saat distribusi ke ruang perawatan. Kedua hal inilah yang memotivasi penulis untuk meneliti apakah monitoring obat dan identifikasi MRPs berpengaruh terhadap keselamatan pasien di Rumah Sakit $\mathrm{X}$ Tangerang

\section{Metode Penelitian}

Penelitian ini menggunakan metode kualitatif dengan tipe riset deskriptif analitik dengan sumber data sekunder dan primer. Dengan menggunakan metode penelitian ini akan diketahui hubungan yang signifikan antara variabel yang diteliti, sehingga menghasilkan kesimpulan yang akan memperjelas objek yang diteliti.

\section{Hasil dan Pembahasan}

\section{A. Hasil Penelitian}

a. Gambaran Karakteristik Responden Gambaran karakteristik responden berupa usia, jenis kelamin, pendidikan, dan masa kerja disajikan dalam tabel dibawah ini:

Tabel 1 
Gambaran Karakteristik Responden

\begin{tabular}{|c|c|c|c|}
\hline No & $\begin{array}{c}\text { Karakteristik } \\
\text { Responden }\end{array}$ & Frekuensi $\mathbf{N}=\mathbf{2 8}$ & Prosentase (\%) \\
\hline \multirow[t]{3}{*}{1} & Jenis Kelamin & & \\
\hline & a. Perempuan & 24 & 85,71 \\
\hline & b. Laki-laki & 4 & 14,29 \\
\hline \multirow[t]{3}{*}{2} & Tingkat Pendidikan & & \\
\hline & a. DIII Farmasi & 17 & 60,71 \\
\hline & b. S1 Farmasi & 11 & 39,29 \\
\hline \multirow[t]{3}{*}{3} & Status Kepegawaian & & \\
\hline & a. Tetap & 10 & 35,71 \\
\hline & b. Tidak Tetap & 18 & 64,29 \\
\hline \multirow[t]{3}{*}{4} & Pelatihan Patient Safety & & \\
\hline & a. Pernah & 9 & 32,14 \\
\hline & b. Tidak Pernah & 19 & 67,86 \\
\hline \multirow[t]{7}{*}{5} & Usia & & \\
\hline & a. 21-25 tahun & 5 & 17,86 \\
\hline & b. $26-30$ tahun & 8 & 28,57 \\
\hline & c. $31-35$ tahun & 4 & 14,29 \\
\hline & d. 36-40 tahun & 5 & 17,86 \\
\hline & e. 41-45 tahun & 4 & 14,29 \\
\hline & f. 46-50 tahun & 2 & 7,14 \\
\hline \multirow[t]{6}{*}{6} & Masa Kerja & & \\
\hline & a. $<5$ tahun & 15 & 53,57 \\
\hline & b. $6-10$ tahun & 5 & 17,86 \\
\hline & c. $11-15$ tahun & 4 & 14,29 \\
\hline & d. 16-20 tahun & 3 & 10,71 \\
\hline & e. 21-25tahun & 1 & 3,57 \\
\hline
\end{tabular}

Berdasarkan Tabel di atas, distribusi frekuensi responden didasarkan pada jenis kelamin sebagian besar responden adalah perempuan sebanyak 24 responden $(85,71 \%)$ dan jumlah laki-laki 11 responden dengan prosentase 14,29\%. Dari hasil juga diketahui bahwa distribusi frekuensi responden didasarkan pada kelompok tingkat pendidikan sebagian besar responden berpendidikan DIII Keperawatan sebanyak 17 responden $(60,71 \%)$ dan SI sejumlah 11 responden dengan prosentase $39,29 \%$. Status kepegawaian responden dikategorikan menjadi dua kelompok yaitu tetap dan tidak tetap. Pada sebagian besar responden memiliki status kepegawaian adalah tidak tetap sebesar $64,29 \%$ dengan jumlah responden sebanyak 18 responden, sementara sisanya karyawan tidak tetap berjumlah 10 responden dengan prosentase $35,71 \%$.

Jumlah responden yang pernah mengikuti pelatihan keselamatan pasien masih kurang sebanyak 9 orang $(32,14 \%)$ dan responden yang belum mengikuti pelatihan keselamatan pasien cukup tinggi yaitu sebanayk 19 orang $(67,86 \%)$. Distribusi responden berdasarkan kelompok usia menunjukkan bahwa responden menyebar hampir merata pada 
kelompok usia 21-25 tahun dan 36-40 tahun dengan 31-35 tahun dan 41-45 tahun yaitu pada rentang 14,29 $17,86 \%$ dan usia terbanyak pada kelompok usia 26-30 sebannyak 8 responden serta terdapat $7,14 \%$ responden terendah termasuk dalam kelompok 46-50 tahun. Berdasarkan masa kerja frekuensi distribusi responden dengan masa kerja di bawah 5 tahun sebanyak 15 orang $(53,57 \%)$ dan untuk kelompok masa kerja 11-15 tahun sebanyak 5 responden dengan prosentase $17,86 \%$. Untuk kelompok responden dengan masa kerja 16-20 tahun sebanyak 3 responden dengan prosentase $10,71 \%$. Di masa kerja 21 25 tahun merupakan responden paling sedikit sebanyak 1 responden dengan prosentase 3,57\%. Hal ini berarti tenaga farmasi paling banyak masa kerja pada range waktu antara $<5$ Tahun.

Tabel 2

Responden Untuk Monotoring Obat

\begin{tabular}{llc}
\hline No & \multicolumn{1}{c}{ Indikator } & Rata Rata Indeks \\
\hline 1. & Pengkajian dan pelayananresep & 16,40 \\
\hline 2 & Penelusuran riwayat penggunaan obat & 15,80 \\
\hline 3 & Rekonsiliasi Obat & 17,68 \\
\hline 4 & Pelayanan Informasi Obat (PIO) & 15,76 \\
\hline 5 & Konseling & 13,97 \\
\hline 6 & Visite & 14,40 \\
\hline 7 & Pemantauan Terapi Obat (PTO) & 17,93 \\
\hline 8 & Monitoring efek samping obat (MESO) & 14,60 \\
\hline 9 & Evaluasi penggunaan Obat (EPO) & 16,20 \\
\hline 10 & Dispensing Sediaan steril & 18,00 \\
\hline 11 & $\begin{array}{l}\text { Pemantauan kadar Obat dalam darah } \\
\text { (PKOD) }\end{array}$ \\
\hline & Rata-rata & 18,20 \\
\hline
\end{tabular}

Berdasarkan pada Tabel 2 diatas, terlihat bahwa:

1. Indeks pada indikator pengkajian dan pelayanan resep diperoleh ratarata indeks sebesar 16,40. Hasil ini menunjukan bahwa indikator pengkajian dan pelayanan resep pada variabel monitoring obat adalah di kategori sedang.

2. Indeks pada indikator penelusuran riwayat penggunaan obat diperoleh rata-rata indeks sebesar 15,80. Hasil ini menunjukan bahwa indikator penelusuran riwayat penggunaan obat pada variabel monitoring obat adalah di kategori sedang.

3. Indeks pada indikator rekonsiliasi obat diperoleh rata-rata indeks sebesar 17,68. Hasil ini menunjukan bahwa indikator rekonsiliasi obat pada variabel monitoring obat adalah di kategori sedang.

4. Indeks pada indikator Pelayanan Informasi Obat (PIO) diperoleh rata-rata indeks sebesar 15,76. Hasil ini menunjukan bahwa indikator Pelayanan Informasi Obat (PIO) pada variabel monitoring obat adalah di kategori sedang.

5. Indeks pada indikator konseling diperoleh rata-rata indeks sebesar 13,97. Hasil ini menunjukan bahwa indikator konseling pada variabel monitoring obat adalah di kategori sedang. 
6. Indeks pada indikator visite diperoleh rata-rata indeks sebesar 14,40. Hasil ini menunjukan bahwa indikator visite pada variabel monitoring obat adalah di kategori sedang.

7. Indeks pada indikator Pemantauan Terapi Obat (PTO) diperoleh ratarata indeks sebesar 17,93. Hasil ini menunjukan bahwa indikator Pemantauan Terapi Obat (PTO) pada variabel monitoring obat adalah di kategori sedang.

8. Indeks pada indikator Monitoring Efek Samping Obat (MESO) diperoleh rata-rata indeks sebesar 14,60. Hasil ini menunjukan bahwa indikator Monitoring Efek Samping Obat (MESO) pada variabel monitoring obat adalah di kategori sedang.

9. Indeks pada indikator Evaluasi Penggunaan Obat (EPO) diperoleh rata-rata indeks sebesar 16,20. Hasil ini menunjukan bahwa indikator Evaluasi Penggunaan Obat (EPO) pada variabel monitoring obat adalah di kategori sedang.

10.Indeks pada indikator dispensing sediaan steril diperoleh rata-rata indeks sebesar 18,00. Hasil ini menunjukan bahwa indikator dispensing sediaan steril pada variabel monitoring obat adalah di kategori sedang.

11.Indeks pada indikator Pemantauan Kadar Obat dalam Darah (PKOD) diperoleh rata-rata indeks sebesar 18,20. Hasil ini menunjukan bahwa indikator Pemantauan Kadar Obat dalam Darah (PKOD) pada variabel monitoring obat adalah di kategori sedang.

Berdasarkan Tabel 2 diketahui bahwa sebagian besar responden memberikan penilaian cukup bahwa monitoring obat yang dilakukan mempengaruhi keselamatan pasien. Dan hal ini dapat dilihat dari rata-rata skor jawaban variabel monitoring obat sebesar 16,27 yang berada di kategori skor "Sedang". Kondisi ini memberikan bukti bahwa monitoring obat responden berada pada intensitas yang sedang artinya dengan kualitas monitoring obat di rumah sakit secara baik, tepat dan benar dengan melakukan monitoring obat dengan intesitas skala sedang kepada pasien yang menerima obat akan menurunkan angka kesalahan dalam penerimaan obat.

Tabel 3

Responden Untuk Konseling Obat

\begin{tabular}{ccc}
\hline No & Indikator & Rata-Rata Indeks \\
\hline 1 & Kriteria Pasien & 17,84 \\
\hline 2 & Sarana dan Peralatan & 17,53 \\
\hline & Rata-rata & $\mathbf{1 7 , 6 9}$ \\
\hline
\end{tabular}

Berdasarkan pada Tabel 2 diatas, terlihat bahwa:

1. Indeks pada indikator kriteria pasien diperoleh rata-rata indeks sebesar 17,84. Hasil ini menunjukan bahwa indikator kriteria pasien pada variabel monitoring obat adalah di kategori sedang.
2. Indeks pada indikator sarana dan peralatan diperoleh rata-rata indeks sebesar 17,53. Hasil ini menunjukan bahwa indikator sarana dan peralatan pada variabel monitoring obat adalah di kategori sedang.

Berdasarkan Tabel 3 diketahui bahwa sebagian besar responden memberikan penilaian cukup bahwa 
konseling obat yang dilakukan mempengaruhi keselamatan pasien. Dan hal ini dapat dilihat dari rata-rata skor jawaban variabel konseling obat sebesar 17,69 yang berada di kategori skor "Sedang". Kondisi ini memberikan bukti bahwa konseling obat responden berada pada intensitas yang sedang, hal ini menunjukkan bahwa pengaruh konseling obat dalam intensitas sedang akan mempengaruhi dalam penerapan keselamatan pasien rumah sakit.

Tabel 4

Responden Untuk MRPs

\begin{tabular}{clc}
\hline No & \multicolumn{1}{c}{ Indikator } & Rata rata Indeks \\
\hline $\mathbf{1}$ & Benar Pasien & 21,60 \\
\hline $\mathbf{2}$ & Benar Obat & 23,10 \\
\hline $\mathbf{3}$ & Benar Dosis & 20,20 \\
\hline $\mathbf{4}$ & Benar Waktu & 23,45 \\
\hline $\mathbf{5}$ & Benar Rute Pemberian & 22,50 \\
\hline $\mathbf{6}$ & Benar Informasi & 21,60 \\
\hline $\mathbf{7}$ & Benar Dokimentasi & 22,43 \\
\hline & Rata-rata & 22,13 \\
\hline
\end{tabular}

Berdasarkan pada Tabel 2 diatas, terlihat bahwa:

1. Indeks pada indikator Benar Pasien diperoleh rata-rata indeks sebesar 21,60. Hasil ini menunjukan bahwa indikator Benar Pasien pada variabel identifikasi MRPs adalah di kategori tinggi.

2. Indeks pada indikator Benar Obat diperoleh rata-rata indeks sebesar 23,10. Hasil ini menunjukan bahwa indikator Benar Obat pada variabel identifikasi MRPs adalah di kategori tinggi.

3. Indeks pada indikator Benar Dosis diperoleh rata-rata indeks sebesar 20,20. Hasil ini menunjukan bahwa indikator Benar Dosis pada variabel identifikasi MRPs adalah di kategori sedang.

4. Indeks pada indikator Benar Waktu diperoleh rata-rata indeks sebesar 23,45. Hasil ini menunjukan bahwa indikator Benar Waktu pada variabel identifikasi MRPs adalah di kategori tinggi.
5. Indeks pada indikator Benar Rute Pemberian diperoleh rata-rata indeks sebesar 22,50. Hasil ini menunjukan bahwa indikator Benar Rute Pemberian pada variabel identifikasi MRPs adalah di kategori tinggi.

6. Indeks pada indikator Benar Informasi diperoleh rata-rata indeks sebesar 21,60. Hasil ini menunjukan bahwa indikator Benar Informasi pada variabel identifikasi MRPs adalah di kategori tinggi.

7. Indeks pada indikator Benar Dokumentasi diperoleh rata-rata indeks sebesar 22,43. Hasil ini menunjukan bahwa indikator Benar Dokumentasi pada variabel identifikasi MRPs adalah di kategori tinggi.

Berdasarkan Tabel 4 dapat disimpulkan bahwa sebagian besar responden memberikan penilaian tinggi bahwa Identifikasi MRPs yang dilakukan mempengaruhi keselamatan pasien. Dan hal ini dapat dilihat dari rata-rata skor jawaban variabel 
Identifikasi MRPs sebesar 22,13 yang berada di kategori skor "Tinggi". Kondisi ini memberikan bukti bahwa Identifikasi MRPs responden berada pada intensitas yang tinggi, artinya sistem pencatatan dan pelaporan yang benar serta evaluasi yang dilakukan setiap hari dalam memonitoring pemberian obat kepada pasien, maka akan menurunkan angka kejadian kesalahan yang tinggi dalam prosedur pemberian obat.

Tabel 5

Responden Untuk Keselamatan Pasien

\begin{tabular}{clc}
\hline No & \multicolumn{1}{c}{ Indikator } & Rata rata Indeks \\
\hline $\mathbf{1}$ & Ketepatan Identifikasi pasien & 20,00 \\
\hline $\mathbf{2}$ & Peningkatan komunikasi yang & 22,40 \\
\hline $\mathbf{3}$ & $\begin{array}{l}\text { Peningkatan keamanan dalam } \\
\text { pemberian obat dan obat yang } \\
\text { perlu di waspadai }\end{array}$ & 21,60 \\
\hline $\mathbf{4}$ & Kepastian tepat lokasi, tepat & \\
\hline $\mathbf{5}$ & Pengurangan resiko terjadinya & 24,40 \\
\hline $\mathbf{6}$ & $\begin{array}{l}\text { Pengurangan resiko pasien } \\
\text { jatuh }\end{array}$ & 22,70 \\
\hline & Rata-rata & 22,47 \\
\hline
\end{tabular}

Berdasarkan pada Tabel 5 diatas, terlihat bahwa:

1. Indeks pada indikator ketepatan identifikasi pasien diperoleh ratarata indeks sebesar 20,00. Hasil ini menunjukan bahwa indikator ketepatan identifikasi pasien pada variabel keselamatan pasien adalah di kategori sedang.

2. Indeks pada indikator peningkatan komunikasi yang efektif diperoleh rata-rata indeks sebesar 22,40. Hasil ini menunjukan bahwa indikator peningkatan komunikasi yang efektif pada variabel keselamatan pasien adalah di kategori tinggi.

3. Indeks pada indikator peningkatan keamanan dalam pemberian obat dan obat yang perlu di waspadai diperoleh rata-rata indeks sebesar 21,60. Hasil ini menunjukan bahwa indikator peningkatan keamanan dalam pemberian obat dan obat yang perlu di waspadai pada variabel keselamatan pasien adalah di kategori tinggi.
4. Indeks pada indikator kepastian tepat lokasi, tepat prosedur, tepat pasien diperoleh rata-rata indeks sebesar 24,40. Hasil ini menunjukan bahwa indikator kepastian tepat lokasi, tepat prosedur, tepat pasien pada variabel keselamatan pasien adalah di kategori tinggi.

5. Indeks pada indikator pengurangan risiko terjadinya infeksi terkait pelayanan kesehatan diperoleh ratarata indeks sebesar 22,70. Hasil ini menunjukan bahwa indikator pengurangan risiko terjadinya infeksi terkait pelayanan kesehatan pada variabel keselamatan pasien adalah di kategori tinggi.

6. Indeks pada indikator pengurangan risiko pasien jatuh diperoleh ratarata indeks sebesar 22,47. Hasil ini menunjukan bahwa indikator pengurangan risiko pasien jatuh pada variabel keselamatan pasien adalah di kategori tinggi.

Berdasarkan Tabel 5 dapat disimpulkan bahwa sebagian besar 
responden memberikan penilaian tinggi bahwa keselamatan pasien yang dilakukan mempengaruhi kondisi pasien itu sendiri. Dan hal ini dapat dilihat dari rata-rata skor jawaban variabel Keselamatan Pasien sebesar 22,26 yang berada di kategori skor
"Tinggi". Kondisi ini memberikan bukti bahwa Keselamatan Pasien responden berada pada intensitas yang tinggi dimana memberikan bukti bahwa keselamatan pasien telah memberikan manfaat atau kegunaan yang besar kepada responden.

Tabel 6

Hasil Analisis Korelasi

\begin{tabular}{lcccl}
\hline Vaiabel Independen & $\begin{array}{c}\text { Variabel } \\
\text { Dependen }\end{array}$ & $\begin{array}{c}\text { Koefisien } \\
\text { Korelasi }\end{array}$ & p-value & Keterangan \\
\hline Motoring Obat $(\mathrm{X} 1)$ & Penerapan & 0,375 & 0,049 & Signifikan \\
\hline Konseling Obat(X2) & Keselamatan & 0,200 & 0,018 & Signifikan \\
\hline Identifikasi MRPs (X3) & Pasien & 0,848 & 0,000 & Signifikan \\
\hline
\end{tabular}

Berdasarkan pada hasil analisis korelasi pada Tabel diatas ditunjukkan bahwa semua variabel independen memiliki p-value kurang dari 0,05 (p < $0,05)$. Hal ini membuktikan bahwa variabel Monitoring Obat (X1), Konseling Obat (X2), dan Identifikasi MRPs (X3) memiliki hubungan signifikan dengan Penerapan Keselamatan Pasien

1. Koefisien korelasi pada monitoring obat mengandung pengertian bahwa semakin baik variabel monitoring obat, maka penerapan keselamatan pasien semakin baik. Contohnya dengan tingkat kesalahan yang kecil seperti penerapan 7 benar dalam pemberian metode obat maka akan memperkecil juga kesalahan dalam pemberian obat kepada pasien.

2. Koefisien korelasi pada konseling obat mengandung pengertian bahwa semakin baik variabel konseling obat, maka penerapan keselamatan pasien semakin baik. Contohnya dengan penerapan informasi (konseling obat) kepada pasien sehingga pasien mengerti dan paham efek obat yang akan diminum, maka menurunkan angka kesalahan konsumsi obat pada pasien yang berakibat keracunan dan kematian akan efek obat dapat dihindari.

Koefisien korelasi pada Identifikasi MRPs mengandung pengertian bahwa semakin baik variabel Identifikasi MRPs, maka penerapan keselamatan pasien semakin baik. Contohnya dengan petugas farmasi selalu mengecek ketepatan pemberian obat yang dimulai dari identifikasi terhadap pemberian obat kepada pasien sampai tahap evaluasi jika dilakukan dengan benar dan tepat sesuai dengan prosedur maka akan memperkecil kesalahan pemberian obat (Setyani \& Putri, 2020). 
Tabel 7

Hasil Analisa Uji t

\begin{tabular}{lcccc}
\hline \multicolumn{1}{c}{ Varabel Independen } & B & T & Sig. & Keterangan \\
\hline Monitoring Obat (X1) & $-0,162$ & $-2,845$ & 0,009 & Berpengaruh Signifikan \\
\hline Konseling Obat (X2) & 0,411 & 2,444 & 0,002 & Berpengaruh Signifikan \\
\hline Identifikasi MRPs (X3) & 0,330 & 7,504 & 0,000 & Berpengaruh Signifikan \\
\hline
\end{tabular}

Berdasarkan pada tabel diatas pengujian secara parsial untuk masingmasing variabel diperoleh hasil sebagai berikut:

1. Pengaruh secara parsial dari variabel Monitoring Obat (X1) terhadap penerapan keselamatan pasien (Y) memiliki hasil estimasi diperoleh nilai t hitung 2,845 lebih besar dari nilai t tabel 2,063 serta nilai signifikansi 0,009 , hal ini berarti lebih kecil dari $\alpha=0,05$. Dari hasil uji statistik secara parsial tersebut maka Ho ditolak dan sebaliknya $\mathrm{Ha}$ diterima, sehingga dapat disimpulkan bahwa variabel Monitoring Obat berpengaruh signifikan terhadap penerapan keselamatan pasien. Nilai beta dalam Unstandardized Coefficients variabel motivasi menunjukkan angka sebesar 0,162 , yang artinya adalah besaran koefisien monitoring obat terhadap keselamatan pasien adalah sebesar 16,2\%. Hal ini menunjukkan bahwa pengaruh monitoring obat memiliki pengaruh secara negatif dan signifikan menurut statistik.

Artinya adalah dengan kualitas monitoring obat di rumah sakit secara baik, tepat dan benar dengan melakukan monitoring secara berkala kepada pasien yang menerima obat akan menurunkan angka kesalahan dalam penerimaan obat yang berakibat kepada keselamatan pasien sehingga disimpulkan bahwa dengan melakukan monitoring secara berkala baik dan tepat akan meningkatkan angka keselamatan pasien dalam penerimaan obat.

2. Pengaruh secara parsial dari variabel Konseling Obat (X2) terhadap penerapan keselamatan pasien memiliki hasil estimasi diperoleh nilai t hitung 2,444 lebih besar dari nilai $t$ tabel 2,063 serta nilai signifikansi 0,002 , hal ini berarti lebih kecil dari $\alpha=0,05$. Dari hasil uji statistik secara parsial tersebut maka $\mathrm{H} 0$ ditolak dan sebaliknya $\mathrm{Ha}$ diterima, sehingga dapat disimpulkan bahwa variabel Konseling Obat berpengaruh signifikan terhadap penerapan keselamatan pasien. Nilai beta dalam Unstandardized Coefficients variabel motivasi menunjukkan angka sebesar 0,411 yang artinya adalah besaran koefisien monitoring obat terhadap keselamatan pasien adalah sebesar $41,1 \%$. Hal ini menunjukkan bahwa konseling obat memiliki pengaruh secara positif dan signifikan menurut statistik.

Artinya adalah dalam proses konseling obat yang diterapkan kepada pasien dengan mengacu kepada pemahaman pengetahuan pasien akan obat yang akan diminum dan menjelaskan aturan pakai obat dengan jelas kepada pasien, maka diharapkan pengetahuan pasien akan konsumsi obat bertambah, sehingga yang berefek kepada kecilnya atau 
menurunnya kesalahan dalam konsumsi obat, keracunan dan efek samping dari obat (Rismawati, 2012).

3. Pengaruh secara parsial dari variabel Identifikasi MRPs (X3) terhadap penerapan keselamatan pasien memiliki niai estimasi diperoleh nilai t hitung 7,504 lebih besar dari nilai $t$ tabel 2,063 serta nilai signifikansi 0,000 , hal ini berarti lebih kecil dari $\alpha=0,05$. Dari hasil uji statistik secara parsial tersebut maka $\mathrm{H} 0$ ditolak dan sebaliknya $\mathrm{Ha}$ diterima, sehingga dapat disimpulkan bahwa variabel Identifikasi MRPs berpengaruh signifikan terhadap penerapan keselamatan pasien. Nilai beta dalam Unstandardized Coefficients variabel motivasi menunjukkan angka sebesar 0,330, yang artinya adalah besaran koefisien Identifikasi MRPs terhadap keselamatan pasien adalah sebesar 33\%. Hal ini menunjukkan bahwa pengaruh monitoring obat memiliki pengaruh secara positif dan signifikan menurut statistik.

Artinya adalah dengan sistem pencatatan dan pelaporan yang benar serta evaluasi yang dilakukan setiap hari dalam Identifikasi MRPs kepada pasien maka akan menurunkan angka kejadian kesalahan prosedur dalam pemberian obat. Dan jika terjadi kesalahan pemberian obat dapat ditanggapi secara cepat, tanggap dan tangkas dalam pemberian obat yang dikarenakan monitoring dan evaluasi perhari yang dilakukan dalam pencatatan pemberian obat.

Tabel 7

Hasil Analisa Uji F

\begin{tabular}{lcccc}
\hline \multicolumn{1}{c}{ Variabel Independen } & Variabel Dependen & F & Sig. \\
\cline { 1 - 1 } Monitoring Obat (X1) & Keselamatan pasien & & \\
\cline { 1 - 1 } Konseling Obat (X2) & $(\mathrm{Y})$ & 33,542 & 0,000 \\
\cline { 1 - 1 } Identifikasi MRPs (X3) & & & \\
\hline
\end{tabular}

Berdasarkan hasil pengujian secara serempak dapat diketahui nilaiFhitung yaitu sebesar 33,542 dan F- tabel dengan $\alpha=5 \%$ adalah 2,990 dan nilai signifikansi sebesar 0,000 . Hal ini berarti lebih kecil dari $\alpha=5 \%$. Dengan demikian HO ditolak dan Ha diterima, artinya bahwa variebel X1 (Monitoring obat), variabel X2 (Konseling Obat) dan variabel X3 (Identifikasi MRPs) secara simultan berpengaruh terhadap Keselamatan Pasien (Y) di Rumah Sakit. Artinya adalah ketiga variabel tersebut bahwa variebel X1 (Monitoring obat), variabel $\mathrm{X} 2$ (Konseling Obat) dan variabel X3
(Identifikasi MRPs) terbukti secara terhitung berpengaruh secara simultan terhadap keselamatan pasien terutama dalam hal pemberian obat di divisi farmasi atau unit farmasi.

\section{Kesimpulan}

Berdasarkan hasil analisis disimpulkan Pengaruh monitoring obat berpengaruh postif dan signifikan terhadap penerapan keselamatan pasien di Rumah Sakit X. Jadi dapat disimpulkan dengan kualitas monitoring obat di rumah sakit secara baik, tepat dan benar dengan melakukan monitoring secara berkala kepada pasien yang menerima obat, akan menurunkan angka 
kesalahan dalam penerimaan obat yang berakibat kepada keselamatan pasien sehingga dapat disimpulkan bahwa dengan melakukan monitoring secara berkala baik dan tepat akan meningkatkan angka keselamatan pasien dalam penerimaan obat semakin meningkat.

Pengaruh konseling obat berpengaruh postif dan signifikan terhadap penerapan keselamatan pasien di Rumah Sakit X. Jadi dapat disimpulkan dalam proses konseling obat yang diterapkan kepada pasien dengan mengacu kepada pemahaman pengetahuan pasien akan obat yang akan diminum dan menerapkan prinsip dari 7 benar sampai 12 benar, maka diharapkan pengetahuan pasien akan konsumsi obat bertambah paham dari efek samping konsumsi obat, sehingga akan menurunkan kecilnya atau kesalahan dalam konsumsi obat, keracunan atau efek samping dari obat yang dikonsumsi.

Pengaruh Identifikasi MRps berpengaruh postif dan signifikan terhadap penerapan keselamatan pasien di Rumah Sakit X. Jadi dapat disimpulkan dengan sistem pencatatan dan pelaporan yang benar serta evaluasi yang dilakukan setiap hari dalam memonitoring pemberian obat kepada pasien, maka akan menurunkan angka kejadian kesalahan prosedur dalam pemberian obat. Dan jika terjadi kesalahan pemberian obat dapat ditanggapi secara cepat, tanggap dan tangkas dalam pemberian obat, hal ini karena adanya konseling dan evaluasi perhari yang dilakukan oleh pihak rumah sakit.

Variebel X1 (Monitoring obat), variabel X2 (Konseling Obat) dan variabel X3 (Identifikasi MRPs) secara simultan berpengaruh positif dan signifikan terhadap Keselamatan Pasien (Y) di Rumah Sakit. Jadi dapat simpulkan ketiga variabel tersebut bahwa $\mathrm{m}$ onitoring obat), konseling obat dan identifikasi MRPs terbukti secara terhitung berpengaruh secara simultan terhadap keselamatan pasien terutama dalam hal pemberian obat di divisi farmasi atau unit farmasi.

\section{BIBLIOGRAFI}

Basabih, M. (2018). Perlukah Keselamatan Pasien Menjadi Indikator Kinerja Rs Blu? Jurnal Administrasi Rumah Sakit Indonesia, 3(2). Google Scholar

Depkes, R. I. (2008). Keputusan Menteri Kesehatan Ri No. 829/Menkes. $\mathrm{Sk} / \mathrm{Iv} / 2008$ Tentang Standar Pelayanan Minimal Di Rumah Sakit. Www. Depkes. Go. Id. Google Scholar

Fingkylestari, P., \& Aisa, S. (2017). Karakteristikibudenganpersalinansectio Caesareadi Rumahsakitumumdewisartika Provinsisulawesitenggara Tahun2016. Poltekkes Kemenkes Kendari. Google Scholar

Hadiyana, A. W. A. (2016). Studi Praktek Pelayanan Kefarmasian Oleh Apoteker Di Apotek Kabupaten Sleman. Google Scholar

Iskandar, E. (2018). Tata Kelola Dan Kepatuhan Penerapan Standar Patient Safety Penyakit Stroke Di Rumah Sakit Dr. Kanujoso Djatiwibowo Tahun 2015. Jurnal Administrasi Rumah Sakit Indonesia, 3(3). Google Scholar

Ismainar, H. (2015). Keselamatan Pasien Di Rumah Sakit. Deepublish. Google Scholar

Kazemian, S., Shauri, N. A. A., Sanusi, Z. M., Kamaluddin, A., \& Shuhidan, S. M. (2017). Monitoring Mechanisms And Financial Distress Of Public Listed Companies In Malaysia. Journal of International Studies, 10(1), 92-109. Google Scholar

Rismawati, E. (2012). Profil Pelayanan Resep Dengan Obat Glibenklamid Di Apotek Wilayah Surabaya (Studi Dengan Metode Simulasi Pasien). 
Universitas Airlangga. Google Scholar

Setiawati, A., \& Bustami, Z. S. (1995). Antihipertensi, Farmakolo Gi Dan Terapi, Edisi Iv, 315-342. Bagian Farmakologi Fakultaskedokteran Universitas Indonesia, Jakarta. Google Scholar

Setyani, W., \& Putri, D. C. A. (2020). Resep Dan Peracikan Obat. Sanata Dharma University Press. Google Scholar
Tan, H. T., \& Khasiat, K. R. O.-O. P. (2007). Penggunaan Dan Efek-Efek Sampingnya. Jakarta: Pt Elex Media Komputindo, 571. Google Scholar

Wongkar, L. (2000). Analisis Waktu Pelayanan Pengambilan Obat Di Apotek Kimia Farma Kota Pontianak Tahun 2000. Tesis. Program Studi Kajian Administrasi Rumah Sakit Universitas Indonesia. Google Scholar

Copyright holder:

Mulisda Mardiantina (2022)

First publication right:

Jurnal Health Sains

This article is licensed under:

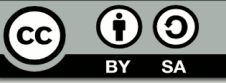

